\title{
ANALISIS PENGARUH DAERAH ASAL SMA TERHADAP NILAI UJIAN MAHASISWA DENGAN MENGGUNAKAN UJI WALD-WOLFOWITZ
}

\section{Analysis of the Effect of Regional High School Origin on Student Value Using Wald-Wolfowitz Test}

\author{
Rola M. Lendert ${ }^{1}$, S. N. Aulele ${ }^{2 *}$, Y. A. Lesnussa ${ }^{3}$ \\ 1,2,3 Jurusan Matematika, Fakultas MIPA Universitas Pattimura
}

Jln. Ir. M. Putuhena, Kampus Unpatti - Poka, Ambon, 97233, Provinsi Maluku, Indonesia

e-mail: salmon.aulele@yahoo.com*

\begin{abstract}
Abstrak: Daerah asal merupakan faktor yang mempengaruhi terhadap perilaku seseorang tentang nilai ujian Mahasiswa Jurusan Matematika yang berasal dari daerah Kota Ambon dan luar Kota Ambon. Dalam penelitian ini, metode yang digunakan untuk melihat dua sampel yang independen adalah Uji Wald-Wolfowitz pada tahun akademik 2016/2017. Tujuan dari penelitian ini untuk mengetahui pengaruh daerah asal SMA terhadap nilai UTS Aljabar Linier Elementer mahasiswa Jurusan Matematika FMIPA Unpatti. Dari hasil penelitian menunjukkan bahwa tidak terdapat perbedaan nilai UTS Aljabar Linier Elementer antara Mahasiswa yang berasal dari Kota Ambon dengan mahasiswa yang berasal dari luar Kota Ambon.
\end{abstract}

Kata Kunci: aljabar linier elementer, pendidikan, uji Wald-Wolfowitz.

\begin{abstract}
Origin is a factor that influences one's behavior about the value of the Mathematics Student's exam that comes from the Ambon city area and outside the city of Ambon. In this research, the method used to look at two independent samples is the Wald-Wolfowitz Test in the academic year 2016/2017. The purpose of this study to determine the influence of the origin of high school to the value of the middle exam of Elementary Linear Algebra in Department Mathematics FMIPA Unpatti. The result shows that there is no difference in the middle exam of Elementary Linear Algebra value between students who are from Ambon city and students who are from outside Ambon city.
\end{abstract}

Keywords: elementary linear algebra, education, Wald-Wolfowitz test.

\section{PENDAHULUAN}

Pendidikan adalah hal mutlak yang wajib dimiliki oleh semua individu, di dalam setiap ajaran agama menganjurkan agar setiap individu wajib berusaha untuk mendapatkan pendidikan. Pendidikan dapat diperoleh melalui jalur formal, non formal, dan informal. Pendidikan nonformal adalah jalur pendidikan di luar pendidikan formal yang dapat dilaksanakan secara terstruktur dan berjenjang. Dalam hal ini, pendidikan nonformal paling banyak terdapat pada usia dini, serta pendidikan dasar sekolah minggu yang terdapat di semua gereja. Selain itu, ada juga berbagai kursus diantaranya kursus musik, bimbingan belajar, dan sebagainya [1]. Pendidikan formal juga merupakan pendidikan yang diselenggarakan di sekolah-sekolah pada umumnya. Jalur pendidikan ini mempunyai jenjang pendidikan yang jelas, mulai dari pendidikan dasar, pendidikan menengah, sampai pendidikan tinggi. Pendidikan informal adalah jalur pendidikan keluarga dan lingkungan berbentuk kegiatan belajar secara mandiri yang dilakukan secara sadar dan bertanggung jawab. Hasil pendidikan informal diakui sama dengan pendidikan formal dan nonformal setelah peserta didik lulus ujian sesuai dengan standar nasional pendidikan [2]. 
Lendert, dkk. | Analisis Pengaruh Daerah Asal SMA...

Perkembangan pemikiran tentang ilmu pendidikan semenjak ilmu tersebut berdiri sebagai disiplin ilmu tampak semakin maju. Hal itu disebabkan oleh kesadaran tinggi di kalangan ilmuwan untuk memecahkan setiap masalah pendidikan secara serius. Dalam sejarah ilmu pendidikan kita mengenal berbagai teori pendidikan yang berkaitan dengan cara penyampaian pelajaran dalam pendidikan formal atau konsep lainnya. Ini suatu pertanda, bahwa ilmu pendidikan sebagai suatu disiplin ilmu senantiasa berkembang karena tuntutan perkembangan sosial dan ilmu pengetahuan salah satunya di perguruan tinggi [3].

Uji Wald-Wolfowitz dapat diterapkan bila ingin diuji hipotesis nol bahwa dua sampel independen berasal dari populasi yang sama atau tidak. Artinya dengan sampel-sampel yang cukup besar. Uji WaldWolfowitz pada prinsipnya menggunakan banyaknya rangkaian yang terdapat pada dua buah sampel. Distribusi sampel diuji berdasarkan pada banyaknya Run dalam kedua sampel. Skala data minimum yang dapat digunakan adalah skala ordinal. Dari latar belakang diatas maka tujuan dalam penelitian ini yaitu untuk mengetahui pengaruh daerah asal SMA terhadap nilai UTS Aljabar Linier Elementer mahasiswa Jurusan Matematika FMIPA Unpatti dengan menggunakan Uji Wald-Wolfowitz.

\section{METODOLOGI}

Penelitian ini menggunakan data nilai ujian mahasiswa Jurusan Matematika FMIPA Unpatti dan kemudian dianalisis dengan menggunakan metode Wold-Wolfowitz. Variabel yang digunakan dalam penelitian ini adalah sebagai berikut.

$X=$ Nilai UTS aljabar linier elementer mahasiswa yang berada di kota Ambon

$Y=$ Nilai UTS aljabar linier elementer mahasiswa yang berasal dari luar kota Ambon

Berikut merupakan prosedur penelitian yang digunakan dalam penelitian ini.

1) Mengumpulkan data penelitian.

2) Menganalisis karakteristik responden

3) Melakukan pengujian atau pengolahan data dengan menggunakan uji Wald-Wolfowitz

4) Analisis hasil pengujian

5) Membuat kesimpulan

\section{HASIL DAN PEMBAHASAN}

\subsection{Karakteristik Responden}

Jumlah responden yang dijadikan sampel dalam penelitian ini adalah 70 mahasiswa yang asal SMA dari Kota Ambon dan asal SMA dari luar Kota Ambon. Data yang digunakan yaitu nilai Ujian Tengah Semester (UTS) mata kuliah Aljabar Linier Elementer pada Semester Gasal Tahun Akademik 2016/2017 di Jurusan Metematika FMIPA Unpatti. Karakteristik responden diklasifikasikan sebagai berikut.

a) Responden Berdasarkan Jenis Kelamin

Berdasarkan jumlah responden yang dijadikan sampel dalam penelitian ini diperoleh data responden berdasarkan jenis kelamin sebagai berikut.

Tabel 1. Responden Berdasarkan Jenis Kelamin

\begin{tabular}{ccc}
\hline Jenis Kelamin & Responden & Persentase (\%) \\
\hline Laki-Laki & 26 & 37,1 \\
Perempuan & 44 & 62,9 \\
Jumlah & 70 & 100 \\
\hline
\end{tabular}


Berdasarkan Tabel 1, terlihat bahwa jumlah responden laki-laki yaitu sebanyak 26 orang atau 37,1\%, sedangkan responden perempuan sebanyak 44 orang atau $62,9 \%$. Hal ini menunjukan bahwa responden perempuan lebih banyak dibandingkan dengan responden laki-laki.

b) Responden Berdasarkan Daerah Asal SMA

Berdasarkan jumlah responden yang dijadikan sampel dalam penelitian ini diperoleh data responden berdasarkan daerah asal SMA sebagai berikut.

Tabel 2. Responden Berdasarkan Daerah Asal SMA

\begin{tabular}{ccc}
\hline Daerah Asal SMA & Responden & Persentase (\%) \\
\hline Kota Ambon & 30 & 42,9 \\
Luar Kota Ambon & 40 & 57,1 \\
Jumlah & 70 & 100 \\
\hline
\end{tabular}

Berdasarkan Tabel 2, terlihat bahwa jumlah responden yang berasal dari Kota Ambon yaitu sebanyak 30 orang atau 42,9\%. Sedangkan responden yang berasal dari luar Kota Ambon sebanyak 40 orang atau $57,1 \%$. Hal ini menunjukan bahwa responden yang berasal dari luar Kota Ambon lebih banyak dibandingkan dengan yang berasal dari Kota Ambon.

\subsection{Analisis Pengaruh Daerah Asal SMA Terhadap Nilai Ujian Mahasiswa}

Dalam penelitian ini akan dilihat pengaruh daerah asal SMA terhadap nilai ujian mahasiswa yang diperoleh dengan menggunakan uji Wald-Wolfowitz. Data yang diperoleh disajikan dalam tabel sebagai berikut.

Tabel 3. Nilai UTS Aljabar Linier ElementerBerdasarkan Daerah Asal Mahasiswa

\begin{tabular}{cc|cc}
\hline \multicolumn{4}{c}{ Daerah Asal SMA } \\
\hline \multicolumn{2}{c}{ Kota } & Ambon & \multicolumn{2}{c}{ Luar Kota } & Ambon \\
\hline 21 & 41 & 21 & 36 \\
21 & 48 & 21 & 37 \\
21 & 51 & 21 & 37 \\
21 & 52 & 21 & 37 \\
21 & 53 & 21 & 37 \\
21 & 59 & 21 & 38 \\
22 & 66 & 21 & 39 \\
29 & 68 & 21 & 39 \\
29 & 68 & 21 & 39 \\
29 & 68 & 22 & 41 \\
33 & 70 & 29 & 44 \\
36 & 72 & 29 & 45 \\
36 & 75 & 29 & 46 \\
40 & 76 & 30 & 48 \\
40 & 81 & 49 & 49 \\
& & 36 & 50 \\
& & 36 & 52 \\
& & 36 & 55 \\
& & 36 & 59 \\
& & 36 & 71 \\
\hline
\end{tabular}

Berdasarkan Tabel 3, terlihat bahwa jumlah mahasiswa yang berasal dari Kota Ambon sebanyak 30 orang dan yang berasal dari luar Kota Ambon 40 orang. Untuk melihat apakah terdapat perbedaan nilai ujian antara mahasiswa yang asal SMA dari Kota Ambon dengan mahasiswa yang asal SMA dari luar Kota Ambon, maka hipotesis yang akan diuji adalah sebagai berikut.

$H_{0}$ : Tidak terdapat perbedaan nilai UTS Aljabar Linier Elementer antara mahasiswa yang asal SMA dari Kota Ambon dengan mahasiswa yang asal SMA dari luar Kota Ambon. 
Lendert, dkk. | Analisis Pengaruh Daerah Asal SMA...

$H_{1}$ : Terdapat perbedaan nilai UTS Aljabar Linier Elementer antara mahasiswa yang asal SMA dari Kota Ambon dengan mahasiswa yang asal SMA dari luar Kota Ambon.

Selanjutnya untuk mendapatkan statistik uji Wald-Wolfowitz yaitu dengan menggabungkan kedua sampel ke dalam satu seri kemudian urutkan dari terkecil sampai dengan terbesar kemudian hitung nilai run-nya. Hasil yang diperoleh disajikan dalam tabel sebagai berikut.

Tabel 4. Hasil Rangking untuk Nilai Run

\begin{tabular}{|c|c|c|c|c|c|c|c|c|c|}
\hline 21 & \multirow{6}{*}{ A } & 21 & & 36 & \multirow{14}{*}{ LA } & 40 & \multirow{3}{*}{ A } & 53 & $\mathrm{~A}$ \\
\hline 21 & & 22 & $\mathrm{~A}$ & 36 & & 40 & & 55 & LA \\
\hline 21 & & 22 & LA & 36 & & 41 & & 59 & $\mathrm{~A}$ \\
\hline 21 & & 29 & \multirow{3}{*}{ A } & 36 & & 41 & \multirow{4}{*}{ LA } & 59 & LA \\
\hline 21 & & 29 & & 36 & & 44 & & 66 & \multirow{5}{*}{ A } \\
\hline 21 & & 29 & & 36 & & 45 & & 68 & \\
\hline 21 & \multirow{8}{*}{ LA } & 29 & \multirow{5}{*}{ LA } & 37 & & 46 & & 68 & \\
\hline 21 & & 29 & & 37 & & 48 & A & 68 & \\
\hline 21 & & 29 & & 37 & & 48 & \multirow{3}{*}{ LA } & 70 & \\
\hline 21 & & 30 & & 37 & & 49 & & 71 & LA \\
\hline 21 & & 30 & & 38 & & 50 & & 72 & \multirow{4}{*}{ A } \\
\hline 21 & & 33 & \multirow{3}{*}{ A } & 39 & & 51 & \multirow{2}{*}{ A } & 75 & \\
\hline 21 & & 36 & & 39 & & 52 & & 76 & \\
\hline 21 & & 36 & & 39 & & 52 & LA & 81 & \\
\hline
\end{tabular}

Berdasarkan Tabel 4, terlihat bahwa nilai run ( $r$ ) yang diperoleh adalah sebesar 21. Karena jumlah mahasiswa yang berasal dari Kota Ambon sebanyak 30 orang dan jumlah mahasiswa yang berasal dari luar Kota Ambon sebanyak 40 orang, maka diperoleh statistik uji Z adalah sebegai berikut.

$$
Z=\frac{r-\mu r}{\sigma r}=\frac{r-\left(\frac{2 \cdot n_{1} \cdot n_{2}}{\mathrm{n}_{1}+\mathrm{n}_{2}}+1\right)-0,5}{\sqrt{\frac{2 \cdot \mathrm{n}_{1} \cdot \mathrm{n}_{2} \cdot\left(2 \cdot \mathrm{n}_{1} \cdot \mathrm{n}_{2}-\mathrm{n}_{1}-\mathrm{n}_{2}\right)}{\left(\mathrm{n}_{1}+\mathrm{n}_{2}\right)^{2} \cdot\left(\mathrm{n}_{1}+\mathrm{n}_{2}-1\right)}}}=\frac{21-\left(\frac{2 \cdot 30 \cdot 40}{30+40}+1\right)-0,5}{\sqrt{\frac{2 \cdot 30 \cdot 40 \cdot(2 \cdot 30 \cdot 40-30-40)}{(30+40)^{2} \cdot(30+40-1)}}}=-3,64
$$

Dari hasil perhitungan diperoleh bahwa nilai $\mathrm{Z}$ adalah sebesar -3,64. Dengan mengacu pada Tabel Area Kritis di bawah kurva normal, maka diperoleh nilai $Z$ hitung sebesar 0,5 $+0,4999=0,9999$. Dengan menggunakan taraf nyata $(\alpha)$ sebesar 0,05 maka diperoleh nilai $\mathrm{Z}$ hitung sebesar 0,9999 lebih besar dari 0,05, maka terima $\mathrm{H}_{0}$ sehingga tidak terdapat perbedaan nilai UTS Aljabar Linier Elementer antara mahasiswa yang asal SMA dari Kota Ambon dengan mahasiswa yang asal SMA dari luar Kota Ambon. Dengan kata lain daerah asal SMA tidak berpengaruh terhadap nilai ujian Aljabar Linier Elementer mahasiswa.

\section{KESIMPULAN}

Berdasarkan hasil dan pembahasan, maka dapat ditarik kesimpulan bahwa tidak terdapat perbedaan nilai UTS Aljabar Linier Elementer antara mahasiswa yang asal SMA dari Kota Ambon dengan mahasiswa yang asal SMA dari luar Kota Ambon. Dengan kata lain, daerah asal SMA tidak berpengaruh terhadap nilai ujian Aljabar Linier Elementer mahasiswa.

\section{DAFTAR PUSTAKA}

[1] S. D. Jalal Fasli, "Perilaku Belajar di Perguruan Tinggi”, Yogyakarta: Pustaka Setia, 2001. 
[2] A. Bandura, Pengertian Supervisi pendidikan, Bandung: Pustaka Setia, 1977.

[3] J. Piaget, "Pengertian Supervisi pendidikan", Bandung: Pustaka Setia, 1977.

[4] P. Duwi, 5 Jam Belajar Olah Data dengan SPSS 17, Yogyakarta, 2009.

[5] S. Santoso, Statistik Parametrik konsep aplikasi dengan SPSS, Elex Media Komputindo, 2014.

[6] S. Siegel, Statistik Non Parametrik untuk ilmu - ilmu Sosial, Jakarta: Gramedia Pustaka Indonesia, 1986.

[7] Widarjono, Pengantar Statistika, Jakarta: PT Gramedia Pustaka Utama, 2010.

[8] R. Ardon, “Aplikasi Analisis Variansi”, Ambon: Skripsi Jurusan Matematika, 2017.

[9] B. Murti, "Penerapan metode statistik non-parametrik dalam ilmu-ilmu kesehatan", Jakarta: PT.Grandmedia pustaka utama, 1996.

[10] Furqon, Pengantar Statistika, Jakarta: PT Gramedia Pustaka Utama, 1999.

[11] A. Ridwan, Rumus dan Data dalam Analisis Statistik, Jakarta: PT Gramedia Pustaka Indonesia, 2010.

[12] A. Pasaribu, "Pengantar Statistik", Cetakan Ke-6, Bandung, 1983.

[13] E. Riadi, "Metode statistika parametrik dan non-parametrik untuk penelitian ilmu-ilmu sosial dan pendidikan", Jakarta: Pustaka Mandiri, 2014.

[14] Sugiyono, "Statistik Non Parametris untuk penelitian", Jakarta: Alfabeta,, 2015.

[15] S. \&. Purwanto, "Statistik untuk Ekonomi dan Keuangan Modern”, Jakarta: PT. Rhineka Cipta, 2009.

[16] J. Supranto, "Statistika teori dan aplikasi. Erlangga", Jakarta, 1986.

[17] Suliyanto, "Statistik Non Parametrik dalam aplikasi penelitian", Jakarta: Penerbit Andi, 2014.

[18] Sugiono, Statistik Untuk Penelitian, Jakarta: Alfabeta, 2006.

[19] V. Gaspersz, Teknik Analisis dalam Penelitian Percobaan, Bandung: Tarsito, 1991. 